\title{
GENETIC POLYMORPHISM OF GLUTATHIONE S-TRANSFERASE M1 (GSTM1) IN PATIENTS WITH SUSCEPTIBLE AND RESISTANT TUBERCULOSIS
}

\author{
Lilia D. TODORIKO ${ }^{1}$, Igor 0 . SEMIANIV ${ }^{1}$, Olga S. SHEVCHENKO ${ }^{2}$, Tetiana M. BILOUS ${ }^{1}$, \\ Marianne M. SEMIANIV ${ }^{1}$, Rostislav S. SHEVCHENKO르, ${ }^{2}$ Volodymyr V. YAKYMETS ${ }^{3}$ \\ ${ }^{1}$ Higher State Educational Establishment „Bukovinian State Medical University“, Chernivtsi, Ukraine \\ ${ }^{2}$ Department of Phtisiology \& Pulmonology of Kharkiv National Medical University, Kharkiv, Ukraine \\ ${ }^{3}$ Diagnostic Center, Rivne, Ukraine
}

Received 8 June 2019, Accepted 05 August 2019

https://doi.org/10.31688/ABMU.2019.54.3.08

\section{Abstract}

The objective of the study. To identify glutathione S-transferase M1 (GSTM1) gene polymorphism in patients with tuberculosis depending on Mycobacterium tuberculosis (MBT) resistance.

Material and methods. The study involved 100 patients with newly diagnosed pulmonary tuberculosis (TB), who had been hospitalized in Chernivtsi Regional TB Dispensary. The control group consisted of 50 healthy individuals. Genomic DNA was isolated from the whole venous blood. GSTM1 polymorphic areas were isolated by means of multicomplex polymerase chain reaction, according to the protocol for instantaneous analysis of polymorphism by Arana et al (1996). Deletion of gene corresponds to the lack of appropriate strips in the electropherogram.

Results. An analysis of the occurrence of alleles and genotypes of GSTM1 gene in patients with pulmonary tuberculosis regarding the MBT resistance version allowed to establish that, under the conditions of pulmonary tuberculosis infection, GSTM1 gene deletion mutation can be found in one out of five $(21.87 \%$

\section{RÉsumé}

Le polymorphisme génétique de la Glutathion S-Transférase M1 (GSTM1) chez les patients avec tuberculose, la version de résistance au MBT

Objectif. Identifier le polymorphisme du gène Glutathion S-Transférase M1 (GSTM1) chez les patients atteints de tuberculose en ce qui concerne la version de résistance au MBT.

Matériels et méthodes. L'étude portait sur 100 patients atteints d'une tuberculose pulmonaire récemment diagnostiquée, qui avaient été hospitalisés au dispensaire régional pour la tuberculose de Tchernivtsi. Le groupe témoin était composé de 50 personnes en bonne santé. L'ADN génomique a été isolé du sang veineux complet. Les zones polymorphes GSTM1 ont été isolées au moyen d'une réaction en chaîne de polymérase multicomplexe, selon le protocole d'analyse instantanée du polymorphisme de Arana et al (1996). La délétion du gène correspond au manque de bandelettes appropriées dans l'électrophérogramme. 
of cases), and the occurrence due to the MBT resistance version is: with newly diagnosed tuberculosis (NDTB) - 17.39\%, with multidrug-resistant tuberculosis (MDR-TB) $35.0 \%$ and polyresistant pulmonary tuberculosis (PRTB) 20.0\%, respectively. According to the nature of the distribution of allelic gene GSTM1, a favorable functional 1 allele prevails (73.29\%) in the normal inbreeding among patients and deficiency of heterozygosity among healthy people, which generally forms a normal population distribution for the European race.

Conclusions. According to the nature of allele distribution of GSTM1 gene, the favorable functional 1 allele prevails $(73.29 \%)$ in case of normal inbreeding in patients $(F=0,20, p>0,05)$ and lack of heterozygote in healthy individuals $(F=0.28 \mathrm{p}=0.033)$, which in general forms a normal population distribution $[\mathrm{OR}=14.06$, $\mathrm{p}=0.005$ ].

Keywords: tuberculosis, deletion polymorphism, glutathione s-transferase M1, resistance, Mycobacterium tuberculosis.

\section{List of abbreviations}

GST - Glutathione-S -transferase

MBT - Mycobacterium tuberculosis

MDR TB - Multidrug-resistant tuberculosis

NDTB - newly diagnosed tuberculosis

PRTB - polyresistant pulmonary tuberculosis

TB - tuberculosis

\section{INTRODUCTION}

According to World Health Organization (WHO), anti-TB drugs are classified into five groups, based on evidence of efficacy, potency and drug class. In the frame of actual used DOTS (Directly Observed Treatment Short Course Chemotherapy) strategy ${ }^{1,2}$, the anti-tuberculosis (TB) treatment is standardized, meaning that all patients receive the same regimens, being included in well-defined groups. The standard treatment has advantages over individualized treatment by preventing prescription errors, appropriate appreciation of drug needs, distribution and monitoring ${ }^{3,4}$. By economical mean, standard treatment shows reduced costs and permits a comparable evaluation of treatment outcomes ${ }^{5}$.

Clinical monitoring of the treatment is essential for recognizing adverse drug effects ${ }^{6}$. Also, it permits the promptly and correct management of disturbances appeared due to the TB treatment. Minor side effects (jaundice, nausea, vomiting) permit the continuation of TB treatment with an associated symptomatic treatment. If the patient develops a major
Résultats. Une analyse de la présence d'allèles et de génotypes du gène GSTM1 chez les patients atteints de tuberculose pulmonaire en ce qui concerne la version de résistance au MBT a permis d'établir que, dans les conditions d'une infection tuberculeuse pulmonaire, une mutation de la délétion du gène GSTM1 pouvait être trouvée dans un cas sur cinq (21,87\% des cas). ), et l'occurrence due à la version résistante au MBT est: avec NDTB - 17,39\%, avec MDR-TB 35,0\% et - PRTB $20,0 \%$ respectivement. Selon la nature de la distribution du gène allélique GSTM1, un allèle fonctionnel favorable 1 prédomine $(73,29 \%)$ dans la consanguinité normale chez les patients et dans le déficit en hétérozygote chez les personnes en bonne santé, ce qui constitue généralement une distribution de population normale pour la race européenne.

Conclusions. Selon la nature de la distribution des allèles du gène GSTM1, l'allèle 1 fonctionnel favorable prévaut $(73,29 \%)$ en cas de consanguinité normale chez les patients $(\mathrm{F}=0,20,>0,05)$ et de manque d'hétérozygote chez les individus en bonne santé $(\mathrm{F}=0,28$ $p=0,033)$, ce qui, en général, forme une distribution de population normale $[\mathrm{OR}=14,06, \mathrm{p}=0,005]$.

Mots-clés: la tuberculose, le polymorphisme de délétion, Glutathion S-Transférase M1, la résistance, Mycobacterium tuberculosis.

side-effect, the responsible drug is stopped and the patient is referred to a specialized health care facility for further management ${ }^{7-9}$.

GST are enzymes of the second phase of detoxification systems which protect the body against endogenous oxidative stress and exogenous toxins, catalyzing conjugation of sulfhydryl groups of reduced glutathione and rendering harmless various electrophilic compounds, including products of lipid and DNA oxidation ${ }^{10-12}$.

The GSTM1 gene is composed of 8 exons spanning a region of 21,244 bases, with transcript length of 1,161 bps and translation length of 218 residues (according to ensemble GRCh37 release 78). The GSTM1 gene is approximately $20 \mathrm{~kb}$ in length and is closely flanked by other mu class gene sequences ${ }^{13,14}$. The end points of the polymorphic GSTM1 deletion are: the left repeated region $5 \mathrm{~kb}$ downstream from the 3 -end of the GSTM2 gene and $5 \mathrm{~kb}$ upstream from the beginning of the GSTM1 gene; the right repeated region $5 \mathrm{~kb}$ downstream from the 3 -end of the GSTM1 and $10 \mathrm{~kb}$ upstream from the 5 -end of 
the GSTM5 gene. The cDNAs encoded by GSTM1 and GSTM2 share a remarkable 99\% sequence identity. The fact that GSTM1 and GSTM2 are physically linked suggests that the frequent deletion of the GSTM1 locus is caused by unequal crossing-over ${ }^{15,16}$. Furthermore, in HeLa cells, it has been confirmed that GSTM2 overexpression, following transient knockdown of GSTM1 and the absence of GSTM1 activity, may be compensated by the overexpression of GSTM2 ${ }^{17}$. Moreover, existence of linkage disequilibrium between GSTM1 and GSTM3 suggests that association between phenotype and GSTM1 genotypes may also reflect polymorphism in GSTM3 or even other GSTM genes ${ }^{18,19}$.

\section{Objective}

To identify GSTM1 gene polymorphism in patients with tuberculosis regarding the MBT resistance version.

\section{Material And methods}

The study involved 100 patients with newly diagnosed pulmonary TB who had been hospitalized in Chernivtsi Regional TB Dispensary, Ukraine. The control group consisted of 50 healthy individuals. Genomic DNA was isolated from the whole venous blood. Glutathione s-transferase M1 (GSTM1) polymorphic areas were isolated by means of multicomplex polymerase chain reaction, according to the protocol for instantaneous analysis of polymorphism. Deletion of gene corresponds to the lack of appropriate strips in the electropherogram.

We used the program STATISTICA, version 10.0.228.8 (StatSoft, Inc.) for statistical analysis of the findings. The difference in the distribution of occurrence of genotypes and their combinations between groups were calculated using $\chi^{2}$ criteria. Differences were regarded as significant at significance level $p<0.05$. The association of genotypes with susceptibility to tuberculosis was judged by the size of the odds ratio (odds ratio, OR).

Statistical processing of the obtained results was carried out by analyzing the contingency tables using the StatisticaBasicAcademic 13 for Windows software package (License Number: 139-956-866). We used the median (Me) interquartile range (Lower - lower quartile, Upper - upper quartile) and sample size (min minimum, max - maximum value). The difference between groups was determined by non-parametric statistics using the Mann-Whitney criteria. To study the independent variables, we used the non-parametric Kruskal-Wallis criteria. The correlation Spearman coefficient $\mathrm{R}$ was calculated to find functional relationships between the parameters, with statistical significance at $\mathrm{p}<0.05$.

The work was performed according to the requirements for researches with the participation of people: Statute of the Ukrainian Association for Bioethics and the GCP norms (1992), requirements and norms of ICH GLP (2002), typical ethics provisions of the Ministry of Public Health of Ukraine 66 dated February 13, 2006.

\section{Results AND discussion}

Despite the fact that the activity of the enzyme glutathione-S-transferase of class $\mathrm{M}$ is encoded by five GST genes of class M (M1-M5), the dominant cause of genetically caused dysregulation of antioxidant activity is deletion (null) polymorphism of the gene GSTM1. Due to the above, we have analyzed the occurrence of alleles and genotypes of GSTM1 gene in patients with pulmonary tuberculosis due to MBT resistance version.

Lack of 0-genotype was found in 214 (73.29\%) cases out of 292 isolated alleles $(n=107)$, while the «mutant» deletion (0-allele) was observed by 2.74 times less frequently - in $78(26.71 \%)$ cases $(\mathrm{n}=39)$ $\left(\left(\chi^{2}=63,34, p<0.001\right)(\right.$ Table 1$)$.

The relative occurrence of 0 -genotype and its absence among TB patients and healthy individuals did not differ significantly ( $>0.05)$. Thus, in both groups the functional allele of gene GSTM1 was found much more frequently: by 3.57 times in the experimental group $\left(\chi^{2}=60.75, \mathrm{p}<0.001\right)$ and by 1.78 times in the control group $\left(\chi^{2}=7.84 \mathrm{~g}=0.005\right)$. The resulting distribution in observation groups reflected the general one in the surveyed population, which was also dominated by those with wild 1 allele by

Table 1. Distribution of deletion polymorphism of the gene glutathione-S-transferase of class M1 (GSTM1)

\begin{tabular}{ccccc}
\hline Study groups & $\begin{array}{c}\text { Experimental group, } \\
\mathrm{n}=96\end{array}$ & Control group, $\mathrm{n}=50$ & $\chi^{2} \mathrm{p}$ & Total, $\mathrm{n}=146(\%)$ \\
\hline No 0-genotype, $\mathrm{n}(\%)$ & $75(78.13)$ & $32(64.0)$ & $\chi^{2}=3.35 \mathrm{p}=0.067$ & $107(73.29)$ \\
\hline $\begin{array}{c}\text { O-genotype, } \\
\mathrm{n}(\%)\end{array}$ & $21(21.87)$ & $18(36.0)$ & $\chi^{2}=3.67 \mathrm{p}=0.052$ & $39(26.71)$ \\
\hline$\chi^{2} \mathrm{p}$ & $\chi^{2}=60.75 \mathrm{p}<0.001$ & $\chi^{2}=7.84 \mathrm{p}=0.005$ & - & $\chi^{2}=63.34 \mathrm{p}<0.001$ \\
\hline
\end{tabular}


Table 2. Analysis of null polymorphism of the gene glutathione-S-transferase of class M1 (GSTM1)

\begin{tabular}{cccccccc}
\hline \multirow{2}{*}{ Groups } & \multicolumn{2}{c}{ Genotypes, alleles, $\mathrm{n}(\%)$} & $\mathrm{PP}$ & $\mathrm{P}_{1}$ & $\mathrm{~F}$ & $\chi^{2}$ & $\mathrm{P}$ \\
\cline { 2 - 5 } & $\mathrm{DD}$ & $1_{\text {allele }}$ & & & & & \\
\hline $\begin{array}{c}\text { Experimental group, } \\
\mathrm{n}=96\end{array}$ & $21(21.87)$ & $75(78.13)$ & 0.41 & 0.59 & 0.20 & 2.33 & $>0.05$ \\
\hline Control group, $\mathrm{n}=50$ & $18(36.0)$ & $32(64.0)$ & 0.54 & 0.46 & 0.28 & 4.56 & 0.033 \\
\hline Total, $\mathrm{n}=146$ & $39(26.71)$ & $107(73.29)$ & 0.46 & 0.54 & 0.24 & 3.27 & $>0.05$ \\
\hline
\end{tabular}

Notes: $1 . \mathrm{P}_{1}$ - relative occurrence of 1 allele; $\mathrm{P}_{\mathrm{D}}$ - relative occurrence of deletion allele D. F - inbreeding factor. 3. $\chi^{2} \mathrm{p}-$ criterion of correctness of ,null“ hypothesis.

Table 3. Occurrence of the gene GSTM1 null genotype in patients with TB due to its type

\begin{tabular}{|c|c|c|c|c|c|}
\hline & Study groups & $\begin{array}{l}\text { No 0-genotype, } \\
n=75(\%)\end{array}$ & $\begin{array}{c}\text { O-genotype, } \mathrm{n}=21 \\
(\%)\end{array}$ & $\begin{array}{c}\text { LOD } \\
{[95 \% \mathrm{CI}]}\end{array}$ & $\chi^{2} p$ \\
\hline \multicolumn{2}{|c|}{$\begin{array}{c}\text { Newly diagnosed tuberculosis, } \mathrm{n}=46 \\
(\%)\end{array}$} & $38(82.61)$ & $8(17.39)$ & $22.56[7.67-66.3]$ & $\begin{array}{l}\chi^{2}=39.13 \\
\mathrm{p}<0.001\end{array}$ \\
\hline \multicolumn{2}{|c|}{$\begin{array}{c}\text { Multidrug resistant tuberculosis, } \mathrm{n}=20 \\
(\%)\end{array}$} & $13(75.0)$ & $7(35.0)$ & $\begin{array}{c}3.45 \\
{[0.94-12.6]}\end{array}$ & $\begin{array}{c}\chi^{2}=3.60 \\
\mathrm{p}=0.056\end{array}$ \\
\hline \multicolumn{2}{|c|}{ Poly-resistant tuberculosis, n=30 (\%) } & $24(80.0)$ & $6(20.0)$ & $\begin{array}{c}16.0 \\
{[4.51-56.7]}\end{array}$ & $\begin{array}{l}\chi^{2}=21.60 \\
\mathrm{p}<0.001\end{array}$ \\
\hline \multirow{3}{*}{$\chi^{2} p$} & NDTB-MDR-TB & $\chi^{2}=18.57 \mathrm{p}<0.001$ & $\chi^{2}<1.0 \mathrm{p}>0.05$ & \multirow{3}{*}{-} & \multirow{3}{*}{ - } \\
\hline & NDTB-PRTB & $\chi^{2}=5.39 \mathrm{p}=0.02$ & $\chi^{2}<1.0 \mathrm{p}>0.05$ & & \\
\hline & MDR-TB-PRTB & $\chi^{2}=4.34 p=0.037$ & $\chi^{2}<1.0 \mathrm{p}>0.05$ & & \\
\hline \multicolumn{2}{|r|}{ Control, n=50 (\%) } & $32(64.0)$ & $18(36.0)$ & $\begin{array}{c}3,16 \\
{[1.40-7.15]}\end{array}$ & $\chi^{2}=7.84 p=0.005$ \\
\hline
\end{tabular}

Note: LOD - logarithm of the odds ratio score; CI - confidence interval; $\mathrm{p}$ - differences in probability; NDTB - newly diagnosed tuberculosis; MDR-TB - multidrug resistant tuberculosis; PRTB poly-resistant pulmonary tuberculosis

2.74 times over those with non-functional 0-genotype ( $\mathrm{p}<0.001$ ).

Race and population analysis of gene GSTM1 null polymorphism showed that the frequency of homozygous null genotype gene appointed above among the examined tuberculosis patients was lower than in European population $(\mathrm{PD}=0.42-0.60$ vs $\mathrm{PD}$ $=0.22, \mathrm{p}<0.05)$ and Asian races $(P D=0.42-0.54$, $\mathrm{p}<0.05$ ), it did not differ significantly from the corresponding figure of the equatorial race $(\mathrm{PD}=$ $0.16-0.36, p<0.05)$. Occurrence of null genotype in the control group of the examined patients did not differ significantly from the rate for Caucasians ( $p>0.05)$. In addition, the occurrence of GSTM1 $0 / 0$-genotype in our experimental $(\mathrm{PD}=0.22)$ and control groups $(\mathrm{PD}=0.36)$ corresponded to averages in Ukrainian (south-eastern and central Ukraine) and some Eastern European populations ( $\mathrm{PD}=0.15-30$ ).

Allelic distribution according to the polymorphic variant of gene GSTM1 among TB patients and healthy individuals in general corresponds to the expected population equilibrium Hardy-Weinberg (Table 2). In quantitative terms, an allele without genotype- 0 is dominant $(\mathrm{P} 1=54.0 \%)$, while the relative occurrence of alleles did not differ significantly. We found statistically significant heterozygote deficiency in the control group $(F=0.28, p=0.033)$, which does not generally cover the entire sample $(F=0.24, p>0.05)$ and shows a normal population distribution.

The occurrence of 00-gene GSTM1 genotype in patients with pulmonary tuberculosis depending on the type is shown in Table 3 . We found significantly more frequent presence of a functional allele than its absence, in patients with newly diagnosed pulmonary tuberculosis (NDTB) by 4.75 times $(\mathrm{p}<0.001)$ and in those with poly-resistant pulmonary tuberculosis (PRTB) by 4 times ( $p<0.001$ ), respectively. There was no substantial difference in frequency in patients with multi-drug resistant tuberculosis (MDR-TB) (p $=0.056$ ). It should be noted that among the carriers of non-functional allele in the experimental group there were more patients with NDTB than those with MDR-TB and PRTB by $2,92\left(\chi^{2}=18.57, \mathrm{p}<0.001\right)$ and $1,58\left(\chi^{2}=5.39, p=0.02\right)$ times. At the same time there were more patients with PRTB and without mutated GSTM1 gene than those with MDR-TB: $32.0 \%$ vs $17.33 \%\left(\chi^{2}=4.34, p=0.037\right)$, respectively. There were no significant differences between the occurrence of certain types of pulmonary tuberculosis (NDTB, MDR-TB, PRTB) among homozygous carriers of the gene GSTM1 of the deletion genotype (Table 4).

An analysis of null polymorphism of the gene GSTM1 heterozygous gene GSTM1, taking 
Table 4. Analysis of null polymorphism of the gene glutathione-S-transferase of class M1 (GSTM1) due to the MBT resistance variation

\begin{tabular}{|c|c|c|c|c|c|c|c|}
\hline \multirow{2}{*}{ Groups } & \multicolumn{2}{|c|}{ Genotypes, alleles, n (\%) } & \multirow{2}{*}{$P_{D}$} & \multirow[b]{2}{*}{$\mathrm{P}_{1}$} & \multirow{2}{*}{$\mathrm{F}$} & \multirow{2}{*}{$\chi^{2}$} & \multirow{2}{*}{$\mathrm{P}$} \\
\hline & $\mathrm{DD}$ & 1 & & & & & \\
\hline NDTB, $n=46(\%)$ & $8(17.39)$ & $38(82.61)$ & 0.39 & 0.61 & 0.09 & 1.32 & $>0.05$ \\
\hline MDR-TB, n=20 (\%) & $\begin{array}{c}7 \\
(35.0) \\
\end{array}$ & $13(75.0)$ & 0.53 & 0.48 & 0.30 & 2.36 & $>0.05$ \\
\hline PRTB, n=30 (\%) & $\begin{array}{c}6 \\
(20.0) \\
\end{array}$ & $24(80.0)$ & 0.37 & 0.63 & 0.28 & 2.23 & $>0.05$ \\
\hline Total, $\mathrm{n}=96$ & $21(21.87)$ & $75(78.13)$ & 0.41 & 0.59 & 0.20 & 2.33 & $>0.05$ \\
\hline
\end{tabular}

Notes: 1. - NDTB - newly diagnosed tuberculosis; MDR-TB - multidrug resistant tuberculosis; PRTB poly-resistant pulmonary tuberculosis. 2. $\mathrm{P}_{1}$ - relative occurrence of I allele; $\mathrm{P}_{\mathrm{D}}$ - relative occurrence of deletion allele $\mathrm{D} ; \mathrm{F}$-inbreeding factor. 4. $\chi^{2} p$ - criterion of the correctness of null hypothesis.

into account diagnosed MBT resistance variation (Table 4), showed normal allelic distribution, which corresponded to the scale of population equilibrium by Hardy-Weinberg ( $p>0.05)$. In quantitative terms, the dominant allele in the experimental group regardless of the type of tuberculosis is functional variant 1 ( $75.0-82.61 \%$ vs $17.39-35.0 \%)$.

Our results coincide with the results of other research. A large randomized study in China found that anti-tuberculosis drug induced hepatotoxicity (ATDH) is a major adverse drug reaction associated for anti-tuberculosis therapy ${ }^{20}$. The glutathione-S-transferases (GST) play a crucial role in the detoxification of hepatotoxic metabolites of anti-tuberculosis drugs. An association between GSTM1 null mutation and increased risk of ATDH has been demonstrated in adults. Given the ethnic differences and developmental changes, our study established the potential impacts of GSTM1 genotype on the development of ATDH in Han Chinese children treated with anti-tuberculosis therapy $y^{18,19,21}$.

\section{Conclusions}

1. Among the patients with pulmonary tuberculosis, one out of five persons ( $21.87 \%$ of cases) was diagnosed with deletion mutation of GSTM1 gene; and the occurrence due to MBT resistance variation is: in NDTB- $17.39 \%$, in MDR-TB - $35.0 \%$ and in PRTB- $20.0 \%$ respectively.

2. According to the nature of allele distribution of GSTM1 gene the favorable functional 1 allele prevails $(73,29 \%)$ in case of normal inbreeding in patients $(\mathrm{F}=0,20, \mathrm{pp}>0,05)$ and lack of heterozygote in healthy individuals $(\mathrm{F}=0.28 \mathrm{p}=0.033)$, which, in general forms a normal population distribution [OR=14.06, $\mathrm{p}=0.005$ ].

3. It has been proved that the determination of the deletion polymorphism of the GSTM1 gene is a prognostic factor that allows the formation of risk groups for the detection of resistant forms of tuberculosis and the possible development of liver damage in such patients.

\section{Compliance with Ethics Requirements:}

„The authors declare no conflict of interest regarding this article"

"The work was performed according to the requirements for researches with the participation of people: Statute of the Ukrainian Association for Bioethics and the GCP norms (1992), requirements and norms of ICH GLP (2002), ethical standards in the Helsinki Declaration of 1975, as revised in 2008, typical ethics provisions of the Ministry of Public Health of Ukraine 66 dated February 13, 2006. The work was approved by Ethical Commission of Kharkiv National Medical University, Ukraine (Protocol No 2 of 02.02.2015; chairmen - MD, professor Ospanova T.S. (+ 38050 9988242)).“

"No funding for this study"

\section{Acknowledgements}

none

\section{References}

1. Langendam MW, van der Werf MJ, Huitric E, Manissero D. Prevalence of inappropriate tuberculosis treatment regimens: a systematic review. Eur Respir J. 2012;39(4):1012-1020.

2. Amaral EP, Conceicao EL, Costa DL, et al. N-Acetyl-cysteine exhibits potent anti-mycobacterial activity in addition to its known anti-oxidative functions. BMC Microbiol. 2016;16(1): 251.

3. Guerra C, Johal K, Morris D, et al. Control of Mycobacterium tuberculosis growth by activated natural killer cells. Clin Exp Immunol. 2012;168(1):142-152.

4. Allen M, Bailey C, Cahatol I, et al. Mechanisms of control of Mycobacterium tuberculosis by NK cells: role of glutathione. Front Immunol. 2015;6:508.

5. Todoriko LD. Allele of xenobiotics metabolism genes of glutathione-S-transferase classes T1(GSTT1) and M1 (GSTM1) 
in patients with pulmonary tuberculosis [Alel'nyy stan heniv biotransformatsiyi ksenobiotykiv hlutation-S-transferazy klasiv T1 (GSTT1) ta M1 (GSTM1) u khvorykh na tuberkul'oz lehen' (Ukr)]. Tuberculosis, Lung Diseases, HIV-Infection. 2016; 25 (2): 73-78.

6. Todoriko LD, Semianiv IO. Improvement of the treatment protocol for newly diagnosed pulmonary tuberculosis, depending on the glutathione-S-transferase gene polymorphism. Eur Respir J. 2015; 46: Suppl. 59: 2/2.

7. Venketaraman V, Millman AC, Salman M, et al. Glutathione levels and immune responses in tuberculosis patients. Microb Pathog. 2008; 44: 255-261.

8. Kasthurinaidu SP, Ramasamy T, Ayyavoo J, et al. GST M1-T1 null allele frequency patterns in geographically assorted human populations: a phylogenetic approach. PLoS One. 2015; 10 (4): 23-27.

9. Teixeira RL, Morato RG, Cabello PH, et al. Genetic polymorphisms of NAT2, CYP2E1 and GST enzymes and the occurrence of antituberculosis drug-induced hepatitis in Brazilian TB patients. Mem Inst Oswaldo Cruz. 2011;106(6):716-724.

10. He L, Gao L, Shi Z, et al. Involvement of cytochrome P450 1A1 and glutathione S-transferase P1 polymorphisms and promoter hypermethylation in the progression of anti-tuberculosis drug-induced liver injury: a case-control study. PLoS One. 2015;10(3): e0119481.

11. Todoriko L, Semianiv I. Analysis of the GSTT1 gene polymorphism in patients with tuberculosis with regard to the version of MBT resistance. Science and Education a New Dimension. Nat and Tech Sci. 2016; 83, IV(9): 61-63.

12. Semianiv IO. Treatment of patients suffering from pulmonary tuberculosis with concomitant damages of hepato-pancreato-biliary system taking into account deletion polymorphism of xenobiotics detoxication system genes of glutathione-S-transferase. Clin and Exp Pathology. 2016;56(2):148-151.
13. Butkiewicz D, Grzybowska E, Phillips DH, Hemminki K, Chorąży M. Polymorphisms of the GSTPl and GSTMl genes and PAH-DNA adducts in human mononuclear white blood cells. Env Mol Mutagen. 2010;35:99-105.

14. Qi L, Zou ZQ, Wang LY, et al. Methylation of the glutathione-S-transferase M3 gene promoter is associated with oxidative stress in acute-on-chronic hepatitis B liver failure. The Tohoku J Exp Med. 2012;228(1):43-51.

15. Timofeeva M, Rosenberg A, Heinrich J, et al. A multiplex real-time PCR method for detection of GSTM1 and GSTT1 copy number. Clin Biochem 2009;42(6):500-509.

16. Çelįk SK, Aras N, Yildirim Ö, et al. Glutathione-S-transferase GSTM 1, null genotype may be associated with susceptibility to age-related cataract. Adv Clin Exp Med. 2015; 24 (1): 113-119.

17. Maggie Ramzy M, Mohei El-Din Solliman M, Hany Abdel-Hafiz A, et al. Genetic polymorphism of GSTM1 and GSTP1 in lung cancer in Egypt. Intern $J$ of Collabor Research on Intern Med EPPublic Health. 2011;3(1):41-51.

18. Li C, Long J, Hu X, Zhou Y. GSTM1 and GSTT1 genetic polymorphisms and risk of anti-tuberculosis drug-induced hepatotoxicity: an updated meta-analysis. Eur J Clin Microbiol EO Infect Dis. 2013;32(7):859-868.

19. Liu F, Jiao AX, Wu XR, et al. Impact of glutathione S-transferase M1 and T1 on anti-tuberculosis drug-induced hepatotoxicity in Chinese pediatric patients. PloS One. 2014;9 (12):e115410.

20. Lagman M, Ly J, Saing T, et al. Investigating the causes for decreased levels of glutathione in individuals with type II diabetes. PLoS One. 2015;10(3):e0118436.

21. Forman HJ, Zhang H, Rinna A. Glutathione: overview of its protective roles, measurement, and biosynthesis. Mol Aspects Med. 2009;30(1-2):1-12. 